\title{
単分子接合における吸着サイトを認識可能な分光法の開発
}

\author{
金子 $\quad$ 哲 $^{1} \cdot$ 村井大午 ${ }^{1} \cdot$ 小本祐貴 $^{1} \cdot$ 藤井慎太郎 $^{1} \cdot$ 中村恒夫 ${ }^{2} \cdot$ 木口 学 $^{1}$ \\ '東京工業大学大学院理工学研究科 凿 152-8551 東京都目黒区大岡山 2-12-1 \\ 2産業技術総合研究所 機能材料 函305-8568 茨城県つくば市梅園 1-1-1 \\ コンピュテーショナルデザイン研究センター
}

（2016年 2 月 9 日受付；2016 年 3 月 16 日掲載決定）

\section{Adsorption Site Recognition in Single Molecular Junctions Spectroscopy}

\author{
Satoshi Kaneko ${ }^{1}$, Daigo Murai ${ }^{1}$, Yuki Komoto ${ }^{1}$, Shintaro Funil ${ }^{1}$, Hisao NaKamura ${ }^{2}$ and Manabu Kiguchi ${ }^{1}$ \\ ${ }^{1}$ Tokyo Institute of Technology, 2-12-1 Ookayama, Meguro-ku, Tokyo 152-8551 \\ ${ }^{2}$ Industrial Science and Technology (AIST), 1-1-1 Umezono, Tsukuba, Ibaraki 305-8568
}

(Received February 9, 2016 ; Accepted March 16, 2016)

\begin{abstract}
The metal-molecule interface, particularly the molecular adsorption site, plays a decisive role in the efficiency and durability of organic electronics and the characteristic variability of molecular electronics. However, precise molecularscale handling of the metal-molecule interface remains to be achieved, owing to technical limitations. Here, we developed a hybrid spectro-electrical technique that enables detailed in situ characterization of the metal-molecule interface at room temperature with single-molecule resolution. This non-destructive technique combines surfaceenhanced Raman spectroscopy and current-voltage measurements to obtain correlated structural and electronic details of a single 1, 4-benzenedithiol molecule suspended between two Au electrodes. Significantly, this technique was found to be sensitive to the molecular adsorption site, thus providing an important step toward the reliable integration of millions of individual molecular components into working devices.
\end{abstract}

KEYWORDS : single molecular junction, metal-molecule interface, surface enhanced Raman scattering

\section{1.は じめに}

表面における分子の吸着構造の決定およびその制御 は, エレクトロニクス, 触媒など様々な分野で重要な課 題である ${ }^{1 \sim 3)}$ 。有機 EL, 有機薄膜トランジス夕, 光増感 太陽電池など有機エレクトロニクスでは, 金属と分子界 面における電子移動がそのデバイス特性を左右する。そ して界面における電子移動は界面構造に依存するので, 界面構造の制御の重要性は明らかである ${ }^{3)}$ 。特に, 単分 子を電極間に架橋させた単分子接合では，個々の分子へ の電子注入が平均化される有機エレクトロニクスと比較 して, 分子の吸着構造の決定, 制御の重要性はより顕著 となる ${ }^{4)}$ 。単分子接合の研究は, 1972 年の分子ダイオー

\footnotetext{
†第 35 回表面科学学術講演会（2015 年 12 月 1 日～3 日) にて発表

E-mail : skaneko@chem.titech.ac.jp
}

ドの理論提案からはじまり ${ }^{5)}, 2000$ 年前後に害際に単分 子接合の伝導度計測が行われ6), 最近ではダイオード, トランジスタ, スイッチ特性など, ょり機能性素子とし ての応用が期待される研究も報告されている ${ }^{7 \sim 12)}$ 。現 在，単分子接合は単分子素子やセンサーへの応用を目指 した研究 ${ }^{12)}$, その特徽的な構造を活かした物性探索 ${ }^{13)}$, そして電子移動の基礎過程を解明するためのモデル系と して ${ }^{14)}$, 様々な視点から活発に研究が行われている ${ }^{4)} 。$ これら機能・物性研究に加え, 非弾性トンネル電子分 光, ショットノイズ, 熱起電力, 電流一電圧特性計測な ど，様々な単分子接合の原子.電子構造解析法の開拓も 行われている ${ }^{13,15 \sim 22)}$ 。これら先端構造解析法を用いるこ とで，水素，窒素，ベンゼンといった小分子を中心に， 構造に基づいた物性議論も可能となってきてい る $^{13,15,21)}$ 。しかしながら，単分子接合の物性に決定的な 役目を担う，金属と分子接合界面の構造を決定できる手 
法は確立されていない。

そこで，本研究は単分子接合における接合界面を含む 単分子接合の構造解析法の開拓を目指した。界面の構造 を決定するために，我々は単分子接合の電流一電圧特性 に注目した ${ }^{18)}$ 。単分子接合の電流一電圧特性は, 界面構 造に関する情報を与えることが理論提案されている。こ の理論提案に基づき，単分子接合の電流一電圧特性計測 に基づく接合界面構造の決定に挑戦した。電極間に架橋 した単分子の構造を明らかにするため, 表面増強ラマン 散乱（SERS）に注目した ${ }^{23-26)}$ 。単分子接合では数ナノ メートルのギャップに分子が架橋されているので，ギャ ップに形成される光増強場を利用するのに最適な構造と なっている。光増強場を利用した SERS は Ag ナノ粒子 基板などで活発に研究され，単分子の SERS も報告され ている ${ }^{26)}$ 。本研究ではSERS を単分子接合に適用するこ とで，架橋分子の構造決定に挑戦した ${ }^{27)}$ 。そして，最終 的に界面構造を含めた単分子接合の構造をすべて決定す るためには，電流一電圧特性，SERS 両方の情報を同時 に得る必要がある。そこで, 本研究では単分子接合の電 流一電圧特性と SERS の同時計測システムを新たに構築 し, 界面構造を含めた単分子接合の構造決定に挑戦し た。構築した装置を 1,4 ベンゼンジチオール単分子接合 に適用することで, 単分子接合の構造決定, そしてサイ 卜選択的な分光法の可能性について検討を行った。

\section{2. 実}

験

単分子接合は MCBJ (mechanically controllable breakjunction）法により作製した。MCBJ とは，Fig. 1 に示す ように弾性基板上に金属電極を固定し，基板を湾曲させ ることで金属電極を機械的に伸張させることで金属線を 破断する手法である ${ }^{4)}$ 。破断後ナノギャップが形成され るが，金属表面に吸着していた分子が熱運動によりギャ ップまで拡散し，電極間を分子が架橋する分子接合が形

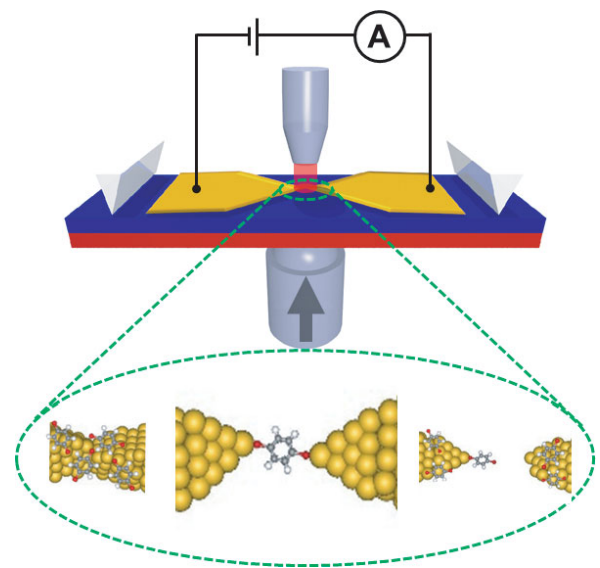

Fig. 1. (color online). Schematic image of the simultaneous SERS and current-voltage characteristics measurement system.

成される。電極間を調整することで架橋分子数を制御 し，単分子接合を作製することができる。本実験では単 分子接合の $\mathrm{I}-\mathrm{V}$ と SERS の同時計測を可能にするための 独自の工夫を施したナノ電極を作製した。ナノ電極は, 研磨したリン青銅基板上にスパッタリングにより $\mathrm{SiO}_{2}$ を $500 \mathrm{~nm}$ 堆積させ，その上にスピンコートによりポリ イミド膜を作製した。続いて，基板上に電子線リソグラ フィーを用いて微細加工電極を作製した。引き出し電極 はメタルマスクを用い $\mathrm{Au}$ をスパッタすることで作製し た。最後に，酸素プラズマでアッシングすることで， $\mathrm{Au}$ ナノ電極の下のポリイミド層を取り除くことで, Fig. 2 (a) に示すような中空のナノブリッジ電極を作製 した。

作製したナノ電極を MCBJ 装置にセットし，1,4-ベン ゼンジチオール（BDT）エタノール溶液（1 mM）を電 極に滴下乾燥させることで分子を電極表面に吸着させ た。ラマン計測は東陽テクニカ社製の Nanofinder30を 用いた。光の強度は $70 \mathrm{~mW}$, 波長は $785 \mathrm{~nm}$, 倍率 50 倍
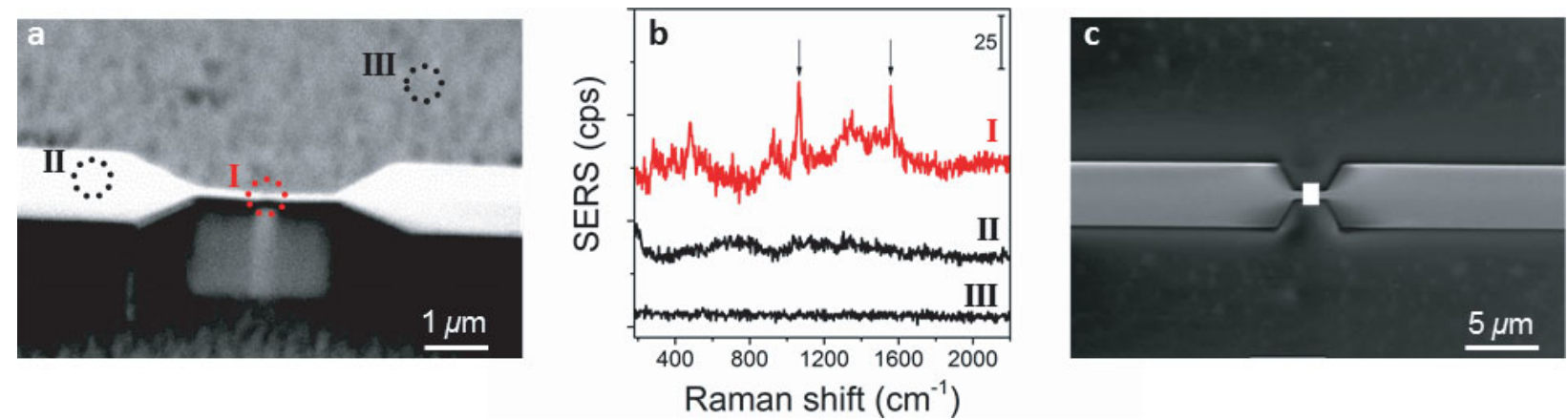

Fig. 2. (color online). (a) SEM image of the nanofabricated Au electrode. (b) Raman spectra collected from the nano-gap between $\mathrm{Au}$ electrodes (I), the surrounding $\mathrm{SiO}_{2}$ layer (II), and the body of the Au electrodes (III). The positions are indicated in Fig. 2 (a). (c) Integrated SERS intensity map corresponding to the BDT ring breathing mode $\left(\nu_{1}, 1000-1100 \mathrm{~cm}^{-1}\right) \mathrm{on} \mathrm{a}^{-1}$ SEM image of the MCBJ substrate. 
の対物レンズを用いた。ラマンの積算時間は $1 \mathrm{~s}$ に固定 した。単分子接合の電流一電圧特性はケースレー社製の 高速電流-電圧変換アンプ（428）を用いて計測した。

\section{3. 結}

\section{果}

まず，ギャップ近傍の SERS 計測を行った。電極表 面, ギャップ, 基板の上の 3 点におけるラマンスペクト ルの結果を Fig. 2（b）に示す。ギャップのみ, ラマン 信号が計測された。Fig. 2 (c) はBDT のベンゼン環の 伸縮振動（1000-1100 $\mathrm{cm}^{-1}$ ) に由来するラマンシグナル 強度の空間分布を電極の電子顕微鏡像とあわせて表示し たものである。ギャップでのみ増強されていることがわ かり, ギャップの増強場を利用した SERS 計測ができて いることがわかる。続いて, ラマン計測位置をギャップ に合わせ, SERS と I-V の同時計測を行った。Fig. 3 (a) は金属原子接合の形成，分子接合の形成，そして破断 と, 接合における電極間距離を伸張させた際の SERS と 伝導度の同時計測結果の例である。伝導度から三つの領 域 I-III に分けることができる。最初の領域 I では, 接合 の伝導度は $1 \mathrm{G}_{0}\left(2 e^{2} / h\right)$ で, 金単原子接合が形成されて いる。対応する I-V は直線的であった。領域 II では接 合の伝導度は $0.01 \mathrm{G}_{0}$ で, BDT 単分子接合が形成されて いる。 I-V は領域 I とは異なり, 非線形な曲線となった。 また SERS が領域 I と比較して著しく増強されているこ とがわかる。SERS スペクトルでは, C-S 間の伸縮を伴 うベンゼン環の変角振動 $\left(\sim 325 \mathrm{~cm}^{-1}, \nu_{6 \mathrm{a}}\right)$, ベンゼン 環の伸縮振動 $\left(\sim 1065 \mathrm{~cm}^{-1}, \nu_{1}\right), \mathrm{C}=\mathrm{C}$ 伸縮振動 $\left(\sim 1558 \mathrm{~cm}^{-1}, \nu_{8 \mathrm{a}}\right)$ と三つの振動モードが観測され た23,28)。BDT 由来の振動モードが明暸に観測されたこと は, BDT が確かに架橋していることを示している。領 域 III では接合の伝導度は検出限界以下となり, 接合が 破断していることがわかる。観測された SERS が単分子 接合に由来するか明らかにするため, 多数の接合（203 個）について同時計測を行い統計的な解析を行った。 Fig. 4 はSERS が観測された 96 個の接合の伝導度分布 である。ピーク值の伝導度は $0.02 \mathrm{G}_{0}$ であった。先行研 究から BDT 単分子接合の伝導度は $0.01 \mathrm{G}_{0}$ であること がわかっており ${ }^{16,29)}$, ピーク值とのよい一致は, 観測さ れたSERS が単分子接合由来であることを示している。 単分子接合の SERS についてもう少し詳細に検討する。 Fig. 5 (c) は BDT 単分子接合の SERS のベンゼン環の 伸縮振動領域の拡大図である。2つのピークに分裂して いることがわかる。比較のため, BDT 分子膜を平坦な $\mathrm{Au}$ 基板と $\mathrm{Au}$ ナノ粒子で挟んだ系（Fig. 5 (a)), 電気化 学的に荒らした表面上に BDT 分子を吸着させた系 （Fig. 5（b)）について計測した SERS を示す。後者の荒

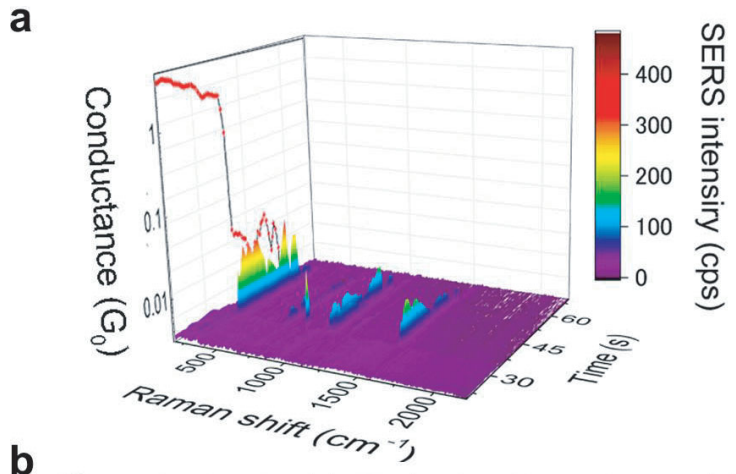

b

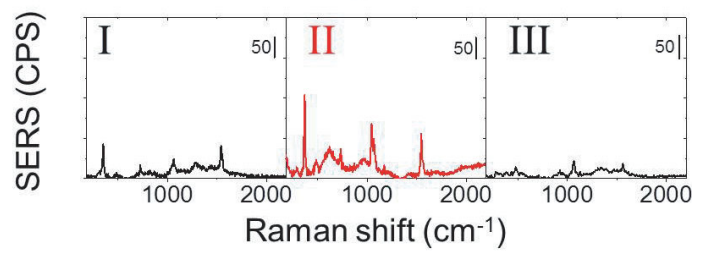

C

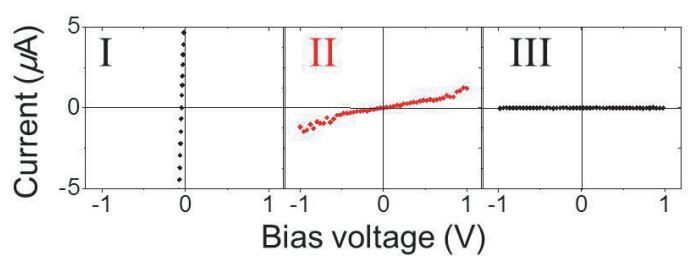

Fig. 3. (color online). (a) Three-dimensional representation of the temporal evolution of SERS and conductance measurements upon rupture of the Au contact. (b) Raman spectra and (c) current voltage characteristics taken at the region I, II, and III, corresponding to metal atomic contacts, single molecular junction, and broken contact.

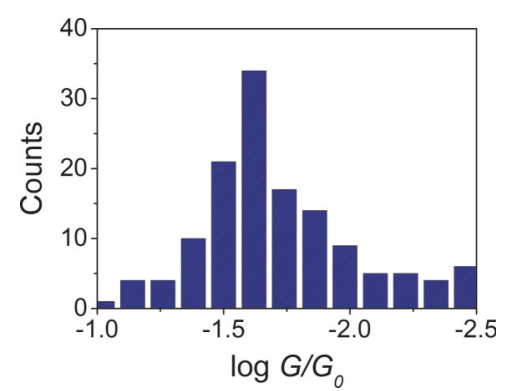

Fig. 4. (color online). Conductance histograms corresponding to molecular junctions (96 samples) with over 10 counts per second among 203 samples.

れた表面では, $\mathrm{BDT}$ 分子は $\mathrm{Au}$ 基板と 1 か所で接触して おり, 前者のナノ粒子系では BDT 分子は $\mathrm{Au}$ ナノ粒子 と $\mathrm{Au}$ 基板と 2 か所で接続しているもの, 基板と 1 か所 で接続しているものの両方が混じっている。対応して, 荒れた表面では $1065 \mathrm{~cm}^{-1}$ に単一ピーク，ナノ粒子系は $1065 \mathrm{~cm}^{-2}$ に加え, $1040 \mathrm{~cm}^{-1}$ にピークが観測された。 分子が金属と相互作用すると, 分子の HOMO から金属 への電荷移動, 金属から LUMOへの電荷移動により分 


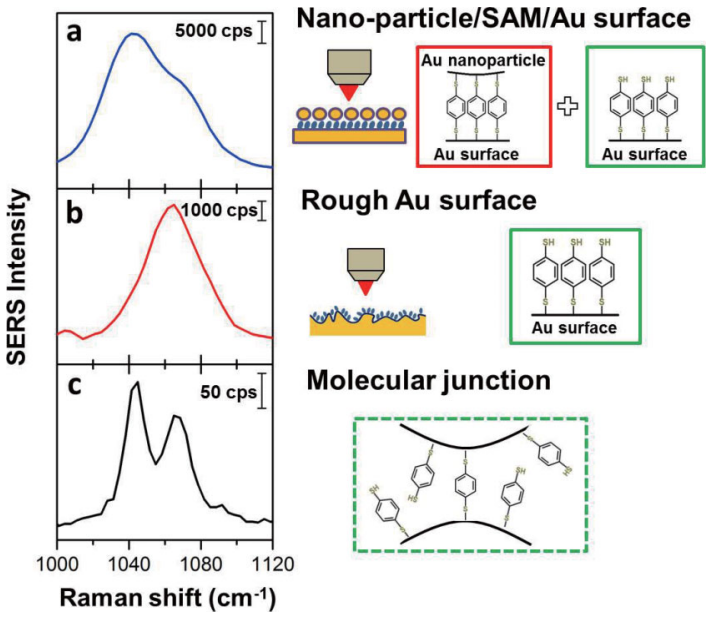

Fig. 5. (color online). SERS spectrum of (a) BDT molecules adsorbed on flat $\mathrm{Au}$ surface and coated with $\mathrm{Au}$ nanoparticles, (b) BDT self-assembled onto a rough Au surface, (c) BDT in a single-molecule junction.

子内の結合は弱められ，分子の振動数は低波数シフトす ることが知られている。1 か所で接続している分子と比 較し，2 か所で接続している分子では，より電荷移動量 は多くなるので, 振動数はより低波数シフトすることに なる。以上の考察により, 単分子接合の SERS で観測さ れた $1040 \mathrm{~cm}^{-1}$ は雨電極に接続している,つまり分子接 合に対応し, $1065 \mathrm{~cm}^{-1}$ はギャップ近傍の片側で吸着し たBDT に対応していることになる。

続いて, 本研究の最大の目的である界面構造の決定に ついて議論する。Fig. 6 (a) は BDT 単分子接合の I-V 特性の例である。対称的な非線形な形状をしていること がわかる。単分子接合の I-V 特性は, 電子が一つの分子 軌道を介して伝導していると仮定すると，式（1）のよう に記述することができる8,9)。ここで，「は金属の連続 的に分布する伝導電子状態と伝導に関与する分子軌道の 波動関数の重なり (カップリング), $\varepsilon_{0}$ は金属のフェル ミ準位と分子軌道のエネルギー差である。

$$
\begin{aligned}
& I(V)=\frac{8 e}{h} \frac{\Gamma_{\mathrm{L}} \Gamma_{\mathrm{R}}}{\Gamma_{\mathrm{L}}+\Gamma_{\mathrm{R}}}\left\{\tan ^{-1}\left(\frac{\frac{\Gamma_{\mathrm{R}}}{\Gamma_{\mathrm{L}}+\Gamma_{\mathrm{R}}} \mathrm{eV}-\varepsilon_{0}}{\Gamma_{\mathrm{L}}+\Gamma_{\mathrm{R}}}\right)\right. \\
& \left.+\tan ^{-1}\left(\frac{\frac{\Gamma_{\mathrm{L}}}{\Gamma_{\mathrm{L}}+\Gamma_{\mathrm{R}}} \mathrm{eV}+\varepsilon_{0}}{\Gamma_{\mathrm{L}}+\Gamma_{\mathrm{R}}}\right)\right\}
\end{aligned}
$$

Fig. 6 （a）に示すように実駼結果を式（1）で fitting す ることで $\varepsilon_{0}, \Gamma$ を求めた。Fig. 6 (b) は 203 個の単分子 接合から求めた「のヒストグラムである。三つのガウ 又関数に分離することができ，「值の異なる三状態が形 成されていることがわかる。「は界面における金属と分
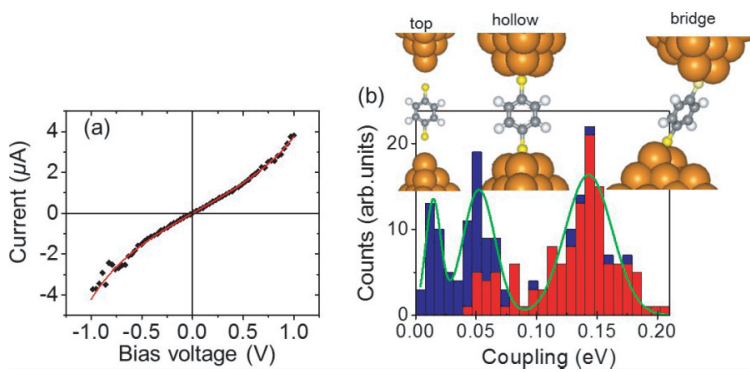

Fig. 6. (color online). (a) Example of I-V characteristic of single BDT molecular junction, and single level tunneling fitting $\left(\Gamma_{\mathrm{L}}=0.089 \mathrm{eV}, \Gamma_{\mathrm{R}}=0.082 \mathrm{eV}, \varepsilon_{0}: 0.88 \mathrm{eV}\right)$. (b) Statistical distribution of $\Gamma$ obtained from the individual fitting of 203 single-molecule I-V characteristics and Gaussian fitting. Red-colored counts correspond to SERS active samples.

子の波動関数の重なりに対応する量であるから, 分子の 吸着構造に大きく依存する。「の異なる三状態が観測さ れたことは，三つの異なる分子吸着形態の存在を示唆し ている。一方で $\varepsilon_{0}$ は分子軌道準位であるので, 吸着構 造依存性は一般に「に比べ小さく, 今回の解析でも三 状態で, あまり変化せず $0.86 \mathrm{eV}$ と求まった。熱起電力 と理論計算からは， $\varepsilon_{0}$ は $1.2 \mathrm{eV}$ であることが報告され て抢り，今回の解析結果とよく一致している ${ }^{16)}$

実験的に得られた結果を整理すると, 三状態 $(\mathrm{H}$, $\mathrm{M}, \mathrm{L})$ の伝導度は $0.02 G_{0}, 0.003 G_{0}, 0.00003 G_{0}, \Gamma$ は $0.14 \mathrm{eV}, 0.05 \mathrm{eV}, 0.01 \mathrm{eV}$ となり, 伝導度, $\Gamma$ ともに H， M, L の順に減少した。金表面における分子の吸着 サイトとしては, atop, bridge, hollow が考えられる。 これら三つの吸着構造をもつ BDT 単分子接合について, 安定構造, 伝導度, 透過率のエネルギー依存性が計算さ れている ${ }^{30,31}$ 。その計算結果によると, BDT 単分子接合 は, Fig. 6 (c) に示すように, bridge では分子が斜め, top, hollow では電極軸に沿って直立して吸着している。 そして, BDT 単分子接合の伝導度は bridge, hollow, atop の順に減少する。また, 透過率のエネルギー依存性 から「も bridge, hollow, atop の順に減少することがわ かっている。以上, 伝導度と「の序列を実験結果と計 算結果を比較することで, I-V 特性で観測された $\mathrm{H}, \mathrm{M}$, Lがそれぞれ bridge, hollow, atop に対応することが明 らかとなった。カップリングに関して吸着構造に基づき 化学的な考察を行う。Au-S 結合では, 結合軸に沿った 化学結合に直接関与する共有結合以外に, $\mathrm{S}$ の $2 \mathrm{p}_{z}$ 軌道 と金の $d_{x y}, d_{z y}$ 軌道も $\pi$ 結合として, 結合に関与する。 Bridge 構造では, 分子が斜めに吸着しており, $\mathrm{S}$ の $2 \mathrm{p}$ と $\mathrm{Au}$ の d 軌道の混じり合いが大きくなる。一方, atop では金原子の直上に分子が垂直に吸着しているので, 
$\mathrm{S} 2 \mathrm{p}$ と金の d 軌道の重なりはほとんどない。Hollow が bridge と atop の中間の状態になる。以上, 分子の吸着 構造を考虑することで, Гの序列に関する計算結果が説 明される。

さらに詳細に I-V と SERS の同時計測結果（Fig. 7 (a, b)）を解析することで, bridge に対応する H サイトの 場合のみ SERS が観測されることが明らかになった。こ の結果は逆に言えば, SERS が観測される単分子接合で は分子が bridge サイトに吸着しているということにな る。I-V と SERS の同時計測を行うことで, サイト選択 的な分光計測に成功した。

Fig. 7 （b）はSERS における $\nu_{1}$ モード強度の $\Gamma$ 依存 性である。接合ごとにデー夕はばらつくので，カップリ ング強度 $\Gamma を$ 領域で区切り, 領域内の SERS 强度を平 均化してプロットした。「の増加とともに SERS 強度が 増加している。「は I-V という電気計測から評価して決 定したもので, SERS 強度は光学計測から求めた量であ る。電気的な物性と光学的な物性を結びつけることに成 功した。

以下, サイト選択性が現れる起源, そしてカップリン グ強度と SERS 強度の相関に関して, SERS 増強機構に 基づき考察する ${ }^{32,33)}$ 。SERS 増強機構には金属ナノ構造 体のプラズモン共鳴に起因する電場増強機構と, 金属と 分子の相互作用に起因する化学効果がある。増強率は電 磁気効果では最大 $10^{10}$, 化学効果では $10^{3}$ である。散乱 断面積を考虑すると, 単分子の SERS が観測されるため には増強率は $10^{12}$ 以上が必要で, 電場増強機構と化学 効果の両方の増強機構が不可欠である。電場増強機構で は増強率はギャップ間隔を含む対向する電極の形状に依 存し, 化学効果では増强率は金属と分子間の相互作用の 大きさに依存する。今回, 金属と分子間のカップリング 強度と SERS 強度の間に相関が観測されており, この相 関には化学効果が効いていると考えられる。化学効果に ついてはいろいろな議論があるが, ここでは光誘起電荷 移動効果について考える。光誘起電荷移動効果とは, 金 属と分子間の相互作用が強い系に扔いて, 分子の HOMO から金属の非占有準位, あるいは金属の占有準 位から分子の LUMO への光学遷移が起こり, 共鳴ラマ ンと同様に SERS 強度が著しく増強される効果である。 BDT 単分子接合では HOMO が LUMO よりフェルミ準 位に近い位置にあり, エネルギー差が $1.2 \mathrm{eV}$ であるこ とが熱起電力計測と理論計算からわかっている。本実験 で用いた励起光の波長は $785 \mathrm{~nm}(1.6 \mathrm{eV})$ であるので, HOMO から金属の非占有準位に光誘起電荷移動が起き ていると考えられる。

金属と分子間のカップリング強度と SERS 強度の間の
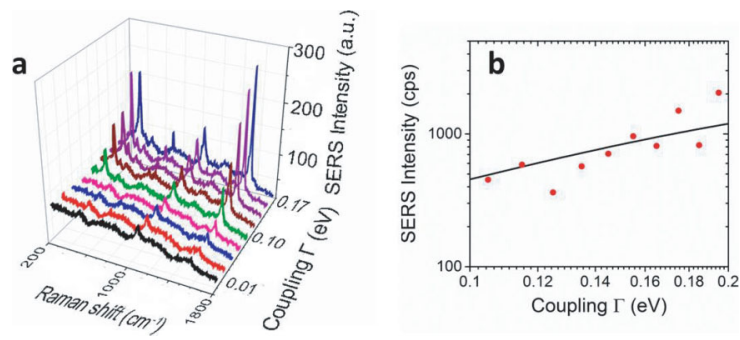

Fig. 7. (color online). (a) Examples of SERS of single BDT molecular junction showing the intensity enhancement as a function of $\Gamma$. From bottom to top $\Gamma: 0.010,0.019,0.044$, $0.073,0.097,0.12,0.13,0.13,0.17 \mathrm{eV}$. (b) Correlation between the average intensity of the SERS signal as a function of $\Gamma$. The red points and solid line are experimental result and the calculated one. The intensity of the theoretical one is normalized to fit the experimental one at $\Gamma=1.2 \mathrm{eV}$.

相関をより定量的に議論するため, 時間依存電場下にお ける 1 準位 Anderson モデルの計算を行った ${ }^{34,35) 。 こ の ~}$ モデルでは, 光による電場で㥶効的な軌道エネルギーが 変調するため, 軌道エネルギーと金属電極のフェルミ準 位のエネルギー差が変化し, 結果, 金属と分子間で電荷 移動が起こると考える。この光誘起電荷移動で, 分子軌 道に扔ける電子（あるいは正孔）の占有数が時間変化す るため, 誘導分極が起こる。簡単化のため, 架橋分子の 双極子の時間変化は, 考えている分子軌道の電子占有数 に比例すると仮定し, 電場による轨道緩和効果や高次の 項を無視すれば, 分極率の振動数依存性は, 軌道電子占 有数のフーリエ変換で表される。ラマン強度は分極率の 基準座標に沿った変位に対する変化量に比例するが，軌 道緩和効果は考えないので, 結局, 分極率は軌道の電子 占有数の基準座標での微分となる。カップリングと SERS 強度に相関があることは, カップリングがもしゼ 口ならば金属と分子間に電荷移動が扔こらず，結果，軌 道の電子占有数も変化しないことからも明らかであろ う。よく知られているように, 電子占有数は, 非平衡グ リーン関数を計算すれば得ることができる。1 準位 Anderson モデルでは時間依存非平衡グリーン関数は, 解析

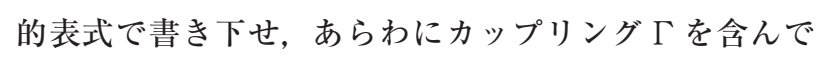
いる。したがって, 分極率の基準座標微分, すなわち SERS 強度はカップリング $\Gamma$ の関数として, 数值計算で 求めることができる。Fig. 7（b）で実線が, 計算で得ら れた SERS 強度のカップリング強度依存性である。カッ プリング強度が増加するに従って SERS 強度が増加して おり, 実験結果とよい一致を示した。SERS が実験的に 観測されるには SERS 強度が一定の閾值以上になる必要 がある。本系では, SERS が観測される接合のカップリ ング強度の閥值が hollow と bridge の境界付近にあり, 
bridge が選択的に観測されたと考えられる。

\section{4. ま め}

本研究では, 単分子接合の SERS と I-V の同時計測シ ステムを新たに構築した。構築した装置を BDT 単分子 接合に適用することで， bridge サイトの単分子接合のみ 選択的に SERS が観測されることがわかった。さらに， カップリング強度が SERS 強度にパワー則に従って増加 することが明らかになった。以上, SERS と I-V の同時 計測により，サイトを区別可能な単分子接合の分光計測 に成功した。

\section{謝 辞}

本研究では物質材料研究機構の塚越一仁博士, 名古屋 工業大学の池田勝佳教授にお世話になった。また本研究 は科学研究費補助金より支援を得て行った。

\section{文献}

1) S.M. Davis, F. Zera and G.A. Somorjai : J. Catal. 85, 206 (1984).

2) H. Sun, Q. Wang, Y. Li, Y.F. Lin, Y. Wang, Y. Yin, Y. $\mathrm{Xu}, \mathrm{C}$. Liu, K. Tsukagoshi, L. Pan, X. Wang, Z. Hu and Y. Shi : Sci. Rep. 4, 7227 (2014).

3) H. Ishii, K. Sugiyama, E. Ito and K. Seki : Adv. Mater. 11, 605 (1999).

4) M. Kiguchi and S. Kaneko : Phys. Chem. Chem. Phys. 15, 2253 (2013).

5) A. Aviram and M. Ratner : Chem. Phys. Lett. 29, 277 (1974).

6) M.A. Reed, C. Zhou, C.J. Muller, T.P. Burgin and J.M. Tour: Science 278, 252 (1997).

7) I. Diez-Perez, J. Hihath, Y. Lee, L.P. Yu, L. Adamska, M.A. Kozhushner, I.I. Oleynik and N.J. Tao : Nat. Chem. 1, 635 (2009).

8) H. Song, Y. Kim, Y.H. Jang, H. Jeong, M.A. Reed and T. Lee : Nature 462, 1039 (2009).

9) M. Kiguchi, T. Ohto, S. Fujii, K. Sugiyasu, S. Nakajima, M. Takeuchi and H. Nakamura : J. Am. Chem. Soc. 136, 7327 (2014).

10) S. Kaneko, C. Motta, G.P. Brivio and M. Kiguchi : Nanotechnology 24, 315201 (2013).

11) T.A. Su, H.X. Li, M.L. Steigerwald, L. Venkataraman and C. Nuckolls : Nat. Chem. 7, 215 (2015)

12) S. Fujii, T. Tada, Y. Komoto, T. Osuga, T. Murase, M. Fujita and M. Kiguchi : J. Am. Chem. Soc. 137, 5939 (2015).

13) M. Kiguchi, O. Tal, S. Wohlthat, F. Pauly, M. Krieger, D. Djukic, J.C. Cuevas and J.M. van Ruitenbeek : Phys. Rev. Lett. 101, 046801 (2008).
14) M. Kiguchi, T. Takahashi, Y. Takahashi, Y. Yamauchi, T. Murase, M. Fujita, T. Tada and S. Watanabe : Angew. Chem., Int. Ed. 50, 5708 (2011).

15) R.H.M. Smit, Y. Noat, C. Untiedt, N.D. Lang, M.C. van Hemert and J.M. van Ruitenbeek: Nature 419, 906 (2002).

16) P. Reddy, S.Y. Jang, R.A. Segalman and A. Majumdar : Science 315, 1568 (2007).

17) S. Kaneko, Y. Nakamura, R. Matsushita, S. MarquesGonzalez and M. Kiguchi : Appl. Phys. Express 8, 065201 (2015).

18) S.H. Choi, B. Kim and C.D. Frisbie : Science 320, 1482 (2008).

19) S. Kaneko, L. Wang, G.F. Luo, J. Lu, S. Nagase, S. Sato, M. Yamada, Z. Slanina, T. Akasaka and M. Kiguchi : Phys. Rev. B 86, 155406 (2012).

20) S. Kaneko, Y. Nakamura, J.J. Zhang, X.B. Yang, J.W. Zhao and M. Kiguchi : J. Phys. Chem. C 119, 862 (2015).

21) S. Kaneko, J.J. Zhang, J.W. Zhao and M. Kiguchi : J. Phys. Chem. C 117, 9903 (2013).

22) S. Kaneko, T. Nakazumi and M. Kiguchi : J. Phys. Chem. Lett. 1, 3520 (2010)

23) R. Matsuhita, M. Horikawa, Y. Naitoh, H. Nakamura and M. Kiguchi : J. Phys. Chem. C 117, 1791 (2013).

24) Z. Liu, S.Y. Ding, Z.B. Chen, X. Wang, J.H. Tian, J.R. Anema, X.S. Zhou, D.Y. Wu, B.W. Mao, X. Xu, B. Ren and Z.Q. Tian : Nat. Commun. 2, 305 (2011).

25) T. Konishi, M. Kiguchi, M. Takase, F. Nagasawa, H. Nabika, K. Ikeda, K. Uosaki, K. Ueno, H. Misawa and K. Murakoshi : J. Am. Chem. Soc. 135, 1009 (2013).

26) S. Nie and S.R. Emery : Science 275, 1102 (1997).

27) S. Kaneko, D. Murai, S. Marques-Gonzalez, H. Nakamura, Y. Komoto, S. Fujii, T. Nishino, K. Ikeda, K. Tsukagoshi and M. Kiguchi: J. Am. Chem. Soc. 138, 1294 (2016).

28) S.W. Joo, S.W. Han and K. Kim : J. Colloid Interface Sci. 240, 391 (2001).

29) X.Y. Xiao, B.Q. Xu and N.J. Tao: Nano Lett. 4, 267 (2004).

30) J. Nara, W.T. Geng, H. Kino, N. Kobayashi and T. Ohno : J. Chem. Phys. 121, 6485 (2004).

31) Y. Kim, T. Pietsch, A. Erbe, W. Belzig and E. Scheer : Nano Lett. 11, 3734 (2011)

32) K. Kneipp, H. Kneipp, I. Itzkan, R.R. Dasari and M.S. Feld : Chem. Rev. 99, 2957 (1999).

33) J.R. Lombardi, R.L. Birke, T.H. Lu and J. Xu : J. Chem. Phys. 84, 4174 (1986).

34) M. Oren, M. Galperin and A. Nitzan : Phys. Rev. B 85, 115435 (2012).

35) H.J.W. Haug and A.-P. Jauho: "Quantum Kinetics in Transport and Optics of Semiconductors" (Springer, 2007). 